\title{
"Love for the People": On the History of "Social Feelings" In Literary Populism of the 1870-1880s
}

\author{
Dyachuk Tatyana Vladimirovna ${ }^{1}$ \\ Associate professor, Department of Humanitarian Education, \\ The Herzen State Pedagogical University of Russia \\ Saint-Petersburg, Russia.
}

(date of receiving: August, 2020; date of acceptance: December, 2020)

\begin{abstract}
The article provides an overview of the works of legal populist prose of the $1870 \mathrm{~s}$ 1880 s and critical articles devoted to it. Populist fiction is interpreted as art inspired by a special "social feeling" - love for the people. The ethics of populism demanded selfdenial from the intellectual in love for the suffering people. At the same time, the affirmation of this feeling in the hero of populist prose took place in a dramatic struggle with the emotions of fear, despair, and guilt. The catastrophe that cut short the creative path of the most gifted of the populist writers - G. I. Uspensky, prompted the critics of the Silver Age to evaluate literary populism as a "tragic romance" between an intellectual and the people.
\end{abstract}

Keywords: Populism, Populist Writers, Love for the People, History of Feelings, G. I. Uspensky, N. N. Zlatovratsky.

1. E-mail: Dia4uk.tanya@yandex.ru 
Issledovatel'skiy Zhurnal Russkogo Yazyka i Literatury, Vol.9, Issue 1, 2021, Pp: 109-125

DOI: $10.52547 /$ iarll.17.109

Article No.: 17.61.20211.109125

\title{
«Любовь к народу»: к истории «социальных чувств» в литературном народничестве 1870-1880-х годов
}

\section{Дячук Татьяна Владимировна ${ }^{1}$}

\author{
Доцент кафедры гуманитарного образования,
}

Российский государственный педагогический университет им. А. И. Герцена,

Санкт-Петербург, Россия.

(дата получения: август 2020 г.; дата принятия: декабрь 2020 г.)

\begin{abstract}
Аннотация
В статье дан обзор произведений легальной народнической прозы 1870-1880-х годов и посвященных ей критических статей. Народническая беллетристика трактуется как искусство, внушенное особым «социальным чувством» - любовью к народу. Этика народничества требовала от интеллигента самоотречения в любви к народу-страдальцу. Вместе с тем утверждение этого чувства в герое народнической прозы происходило в драматичной борьбе с эмоциями страха, отчаяния, вины. Катастрофа, оборвавшая творческий путь самого даровитого из писателей-народников - Г. И. Успенского, побудила критиков Серебряного века оценить литературное народничество как «трагический роман» интеллигента с народом.
\end{abstract}

Ключевые слова: Народничество, Писатели-Народники, Любовь К Народу, История Чувств, Г. И. Успенский, Н. Н. Златовратский.

1. E-mail: Dia4uk.tanya@yandex.ru 


\section{Введение}

Проза легальных писателей-народников 1870-1880-х годов:

Г. И. Успенского, Н.Н.Златовратского, Ф.Д. Нефедова, П. В. Засодимского, Н. И. Наумова, Н. Е. Каронина-Петропавловского, А. О. ОсиповичаНоводворского, Г. А. Мачтета, А. И. Эртеля - редко вовлекается в сферу научной рефлексии и почти никогда - в зону живого читательского интереса. Такое положение дел объясняется, прежде всего, внелитературными причинами.

Начиная с 1890-х годов - заката русского народничества - народническая идеология, а вместе с ней и проза народников-беллетристов, подвергалась уничтожающей критике: авторы «Вех» осуждали народничество как «религию абсолютного осуществления народного счастья» (Франк 1990. 189), русские марксисты ставили в вину народникам их неверие в историческую миссию пролетариата. Санкцией на забвение литературного народничества явилась серия статей, с которыми в конце 1880-х годов выступил Г. В. Плеханов. В прошлом народник, а в описываемые годы убежденный марксист, Плеханов, простился с прежними кумирами, заявив о том, что свои писательские таланты они принесли в жертву «ложному общественному учению» (Плеханов 1948. 532). Этим, по мнению критика, объясняется «унылое настроение» в «нашей народнической литературе» (Плеханов 1948. 533). Писатели-народники умеют только плакать, для чего выработали «даже особый язык, прекрасно характеризующий всю безнадежность их положения» (Плеханов 1948. 532). Тем не менее, как считал Плеханов, «произведения наших народниковбеллетристов надо изучать так же внимательно, как изучаются статистические исследования о русском народном хозяйстве или сочинения по обычному праву крестьян» (Плеханов 1948. 510). Этим впоследствии многократно цитируемым высказыванием марксистский критик исключил народническую 
прозу из сферы искусства, на столетие определив ей маргинальную роль документа сомнительной достоверности. В советские годы изучение литературного народничества велось под знаком его идейной ущербности, аргументированной ссылками на работы В.И. Ленина. Авторы историколитературных исследований были вынуждены повторять идеологемы о социально-политических «иллюзиях» писателей-народников, о «крахе» их «народнических надежд», об их упрямом «идеализме», который не могла сломить даже самая грубая буржуазная действительность.

В настоящей статье речь пойдет о краеугольной «иллюзии» народнической интеллигенции - мечте о любовном союзе с народом.

\section{Основная часть}

Народников питала оптимистическая вера в то, что ход истории управляем, а значит, он может и должен быть направлен к народному благу (апофеозом этой веры явился очерк Успенского «Выпрямила»). Изменить ход истории призвана русская интеллигенция, владеющая знаниями, недоступными народу (Мокшин 2010). Поскольку эти знания были приобретены ценою чужого труда, интеллигенция обязана вернуть «долг» народу-кормильцу, о чем писал П. Л. Лавров в знаменитом четвертом «историческом письме», озаглавленном «Цена прогресса». Идея «долга» и искупления исторического «греха» объединяла народническую интеллигенцию и определяла формы их социального поведения (работа в деревнях в качестве врачей, учителей, землемеров; пропаганда коллективного труда, организация земледельческих коммун, ссудо-сберегательных касс, издание книг для народного чтения и т.д.). По словам народнического публициста Л. Е. Оболенского: «Тут дело шло об искуплении общей вины. Это было религиозно-этическое чувство, вытекающее из великой формулы «грех ваш на детях ваших» (Оболенский 1902. 129). Страдающая деревня сулила интеллигенту выход из тупиков 
отвлеченной мысли, обещала «дело», в котором можно было проявить себя. С «мужиком» были связаны надежды русской интеллигенции на обновление жизни.

Неудача предпринятого интеллигенцией в 1874-1875 годах «хождения в народ» заставила русскую общественность обратиться к проблеме крестьянского менталитета. М. Е. Салтыков-Щедрин в очерке «1 мая» (1879) из цикла «Круглый год» рассуждал: «Мужик - герой современности <..> Ежели мужик так всем необходим, то надо же знать, что он такое, что представляет он собой в действительности, так и in potentia, каковы его нравы, привычки и обычаи, с которой стороны и как к нему подойти. И, к удивлению, оказывается, что узнать это совсем не просто и что мир мужицких отношений значительно сложнее и запутаннее, нежели тот, в котором обыкновенно вращаемся мы, люди интеллигенции» (Салтыков-Щедрин 1972. 468-469).

«Хождение в народ» со всей очевидностью обнаружило, что прежние объяснения крестьянина, предложенные русской литературой, не аутентичны действительности. Требовался новый метод наблюдения и познания народной жизни. Это требование эпохи было воспринято философом и социологом Н. К. Михайловским, предложившим в работе «Что такое прогресс?» (1869) «субъективный метод». Согласно Михайловскому, исследователь не может оставаться безучастным к предмету своих наблюдений: «Субъективным методом называется такой способ удовлетворения познавательной потребности, когда наблюдатель ставит себя мысленно в положение наблюдаемого» (Цит. по: Козьмин 1933. 188). Михайловский обосновал этику сочувствия, обязывающую писателя сопереживать бесправной, но ищущей счастья личности. Таким образом, движущей силой прогресса объявлялось чувство. К подобным выводам пришел и публицист И. И. Юзов-Каблиц. В статье «Ум и чувство как факторы прогресса», опубликованной в 1878 году в газете «Неделя» (№7), он утверждал, что «прогресс социальных форм 
заключается по преимуществу в прогрессе социальных чувств» (Цит. по: Козьмин 1933. 191).

Однако «социальные чувства» не могли возникнуть лишь по требованию абстрагирующей мысли - их необходимо было «воспитать». С трудностями «воспитания» «социальных чувств» столкнулись писатели-народники, отправившиеся «в народ» с художественной задачей - понять и изобразить крестьянство. Ср. описание переживаний народника в деревне у КаронинаПетропавловского: «Он их (мужиков - T. Д.) не любил, но был рад сближению, он любил их за то, чего в нем самом не было. Их жизнь - нечто совсем отличное от их жизни, их мысли - совсем другие. Они были для него всегда чем-тот неизвестным, новым, великим» («Борская колония» (1890) (Каронин 1958. 330). Интеллигенту многое в деревне казалось непонятным, чуждым, пугающим: крестьянская внешность и речь, способы выражения чувств и алгоритм мышления «серого мужика», наконец, поступки крестьянина (бытовые преступления, пьянство, равнодушие к ближнему и т. п.). В народнических текстах зафиксирован широких спектр негативных эмоций, которые вызывала русская деревня в наблюдающем ее интеллигенте (Дячук Мортальное ... 2020). Выработать идеальное чувство сострадания, очищенное от эмоций страха и отчаяния, народническим авторам помогало сознание своей неизбывной виновности перед народом. Приведем фрагмент из цикла Г. Успенского «Из разговоров с приятелями (На тему о власти земли)» (1882). Герой-интеллигент рассказывает, как осенним утром он наблюдал за работой «нелюбимого мужика»:

«Не любил я этого мужика; какая-то беспредельная затаенная алчность - казалось мне на основании многих фактов — алчность неустрашимая - язвой точила его душу; в то время, как лицо всегда было благообразно и благопристойно, глаза только выдавали душевную тайну... Мрачные впечатления деревни, к несчастью, долгие годы 
беспрерывно и без отдыху мной переживаемые, накопили и в моей душе что-то жестокое, неприветливое... Душа как-то закрылась, заперлась точно на замок и отвыкала с каждым днем всё более и более от желания растворяться, раскрывать себя радостному явлению... $<>$ Мы переговаривались с мужиком по словечку чрезвычайно холодно, но вместе деликатно... А думалось мне почему-то одно: «убьет!.. кого? когда? как? Не знаю!.. Просто как-то так стало выходить невольно, несознательно... Поглядишь на такое благообразное лицо, ответишь на благообразный поклон или благообразный вопрос, а сам в то же время почему-то думаешь: «а ведь разорвет, анафема, в клочья!»< ..> Как раз в ту минуту, когда отравленная душа вымучила из себя эту страшную мысль о мужике, который клал дрова и спину которого я созерцал из-за забора, сначала как первая капля дождя, падающая в крышу, послышался какой-то ясный, светлый звук; за ним другой, третий, и вдруг эти странные звуки быстрым и резвым оборотом перешли как-то сразу в развеселый, разудалый, разухабистый вальс из какой-то оперетки». Оперетка, наигранная шарманщиком, «в деревне, среди этих соломенных крыш, этих ободранных полей, рваных полушубков», ошеломила героя, представив ему контраст бедной крестьянской жизни с благополучием городского образованного сословия. Звуки музыки «так превосходно нарисовали этот другой мир, а мое, истомленное однообразием деревенских впечатлений, воображение с такою яркостью отпечатлело его, что я не додумал даже до последней буквы страшного слова «убьет...», как уж и мужик, которого я только что ненавидел, и его черная с глубокими ямами шея и его рваная шапка, словом, всё, всё в нем пробудило во мне взрыв, да именно взрыв необычайной жалости. Звуки вальса рисовали мне бархат, атлас, румяные щеки, обнаженные прекрасные руки,- а то, что подняло в глубине души долго на замок 
116 Issledovatel'skiy Zhurnal Russkogo Yazyka i Literatury, Vol.9, Issue 1, 2021, Pp: 109-125

запертую жалость,- точно каким-то ослепительным светом освещало эти глубокие ямы шеи, эти ужасные мозоли рук, ужасные в буквальном смысле слова, ужасные и грубые как копыта... «Как я мог думать это... убьет?..»-истерически билось у меня где-то не то в голове, не то в сердце... Истерические слезы как-то неудержимо стремились вылиться и оплакать одновременно и неустанные труды этих неустанных рук, и холод изб, и тьму ночей с бьющимся от страшного сна ребенком, и жестокость этого же мужика к родному брату, которого эти же руки ободрали, буквально ободрали, и воровство этими руками в темную ночь чужих дров, и эту неустрашимую алчность, неусыпающую в душе мужика, и черствый хлеб, и грязную соску во рту ребенка... Шарманщик играл, мужик клал холодными руками на холодном ветре холодные и грубые поленья, холодный ветер резал и толкал... а в глубине души разверзалось что-то горячее, как огонь, разливалось жаром рыданий...» (Успенский 1949. 181-183).

Герою-интеллигенту писатели-народники противопоставили «всех трудящихся и обремененных» (Мф. 11: 28), понимая слова Христа как груз страданий и тяжкого труда эксплуатируемого народа. Вопрос героини рассказа Ф. Д. Нефедова «Никитин починок» (1881): «Есть ли на привольном белом свете еще маята, какой не испытал, не изведал бы мужичок Христов?..»определял интенцию народнической беллетристики. Ее нравственновзыскующий пафос был обращен исключительно к интеллигенции, в то время как «мужичку Христову» делегировалась презумпция невиновности. Не случайно, в прозе народников крестьяне часто отождествлялись с невинными детьми, нуждающимися в опеке (Дячук 2020а. 230).

Масштаб личности интеллигента в народническом произведении оценивался в той мере, в какой герой был способен ею жертвовать. Например, 
в повести Златовратского «Золотые сердца» (1877) в качестве обладателей «золотых сердец» представлены интеллигенты, готовые «утечь, отрешиться... А в этом - свет! свет!..» (Златовратский 1988. 284). Об их судьбе старая крестьянка пророчествует: «Умрут за ближних. И Христос, господь наш, спаситель, душу свою положил за овцы, и все, кто искал правды... Все насытились. Сколько было подвижников, мучеников, рыцарей храбрых и благородных, воинов и проповедников - все легли за братии и насытились...» (Златовратский 1988. 183).

Жертвенность определяет отношение интеллигента к народу в произведениях Г. Успенского. Писатель считал, что жертвовать собой ради блага ближнего есть моральный долг русского интеллигента. Так, свой цикл очерков «Волей-неволей» (1884) автор посвящал людям, «волей-неволей обреченным на самопожертвование» (Успенский 1949. 425). Добровольное самоотрицание интеллигента заключалось в признании им нравственного превосходства крестьянина и в отказе от преимуществ своего привилегированного положения. При этом народ, уподобленный Успенским гигантскому организму, «потреблял», «съедал» интеллигента. Первый «крестьянский» цикл Успенского «Из деревенского дневника» (1879) заканчивался рассказом о будущей судьбе народного заступника Андрея Васильевича: «А в результате всего этого оказалось бы только то, что Андрей Васильевич съеден деревней окончательно, «без остатка», а сама деревня, с таким аппетитом скушавшая его, конечно, получила бы пользу для себя, но польза эта, сравнительно с громадностью личной жертвы съеденного, казалась бы ничтожной, едва-едва заметной...» (Успенский 1940. 270). Такой исход народолюбия представлялся Успенскому не только единственно возможным, но и желанным, ведь «самый лучший жизненный результат, которого я могу желать,- это именно быть «потребленным» народною средою без остатка, даже без воспоминания, подобно тому как не вспоминается съеденный час 
назад кусок бифштекса» («Крестьянин и крестьянский труд» (1880) (Успенский 1950. 40)). Трагедия интеллигента, по Успенскому, состояла в том, что его жертва не была принята. Участь народолюбца - оставаться «овцой без стада» (очерк «Овца без стада» (1877)). Так, герой цикла «Без определенных занятий» (1881) народник Лиссабонский, чья фамилия недвусмысленно указывает на пережитую катастрофу, сетовал: «Жалко мне, что мы не потреблены (своевременно) народной средой, жалко потому, что вместе с нами не потреблены народом и наши добрые намерения, жалко потому, что, как мне кажется, как я упорно верую, поглоти нашего брата среда народная право, не было бы этого сумбура, этой тьмы, жестокой путаницы ...» (Успенский 1950. 263).

Самоотрицание личности метафорически уподоблялось растворению капли в стихии воды или земли. Вслед за Михайловским, призывавшим русскую интеллигенцию раствориться «в сером сермяжном море», героиня повести Г. А. Мачтета «Блудный сын» (1882) мечтает, как «через год она потонет в серой деревенской глуши, через год она сольется с массой сельского люда, принесет ему посильную помощь, руки, сердце, голову, - отдаст себя всю, всю!... $<. .>$ Она - маленькая дождевая капля, жадно всасываемая сухою, черною землей, изнемогающею от избытка скрытых собственных плодотворных сил, которой необходима только эта маленькая оплодотворяющая капля, чтобы родить неисчислимые богатства» (Мачтет 1958. 376). Трагический вариант метафоры капли находим в «Записках Степняка» (1879 -1883) А. И. Эртеля, где один из героев признается: «только роль капли, долбящей камень, дает мне мир с моею совестью... Только роль капли» (Эртель 1958. 235).

Самое значительное произведение Н. Н. Златовратского - роман «Устои» (1878-1882) - заканчивался предсмертной исповедью народницы Лизы, которая с отчаянием убеждается в том, что «ее жертва, ее любовь, ее жизнь» не нужны крестьянству, которое «погребает бесследно и безнадежно в своих 
волнах тысячи Лиз, тысячи самоотверженных существований» (Златовратский 1951. 517). Умирая, героиня спрашивает себя: «Куда же стремится этот стихийный океан? Какой смысл для меня в «устоях», если им не нужна любовь, мысль, самопожертвование, если они всем (курсив автора - Т. Д.) не дают смысла жизни, полной и цельной, если любовь, мысль и самопожертвование не могут жить с ними как единое, цельное, неразделимое?» (Там же).

Однако с безотрадным выводом о напрасной жертве Златовратский не мог примириться. Свой творческий путь он завершает былиной «Безумец» (1887), герой которой, пройдя «путь долгий, крестный» (Златовратский 1912. 453), вручает своим наследниками драгоценный «клад»: «Это перлы, которые достал я с глубины народного моря... В них залог его и вашего воскресения и спасения» ((Златовратский 1912. 458).

Трагический оптимизм «безумца» не разделял Г. Успенский. Согласно его наблюдениям, деревня встречает интеллигента суровым предостережением «Не суйся!». Очерк с таким названием в составе цикла Успенского «Крестьянин и крестьянский труд» заканчивался сценой свержения в бездну: «Не имея под ногами никакой почвы, $<\ldots>$ я, как перо, был поднят на воздух дыханием правды Ивана Ермолаевича (крестьянин, главный герой цикла $T$. Д.) и неотразимо почувствовал, как и я, и все эти книжки, газеты, романы, перья, корректуры, даже теленок, не желающий делать того, чего желает Иван Ермолаевич,- все мы беспорядочной, безобразной массой, со свистом и шумом летим в бездонную пропасть...» (Успенский 1950. 55). Аллюзия на евангельский сюжет о бесах, вошедших в стадо свиней и низринувшихся в море ((Мф. 8:28-34; Мк. 5:1-20; Лк. 8:26-37), поддерживаемая скрытой цитатой из стихотворения А. С. Пушкина «Бесы» («Бесконечны, безобразны, / В мутной месяца игре / Закружились бесы разны, / Будто листья в ноябре...»), предельно заостряет конфликт между интеллигенцией и народом. В отличие 
от утонувших бесов из евангельской истории, интеллигенция осуждена на пытку длящегося падения.

Несчастная судьба Г. Успенского, последние десять лет жизни которого прошли в борьбе с душевным недугом, легла трагической тенью на прозу русского народничества. Если 1880-х годах критики иронизировали над народнической «любовью к мужику», уподобляя ее эротическому увлечению (ср., например, слова Михайловского: «Златовратский, можно сказать, влюблен в народ и, как все влюбленные, он не может и не хочет видеть недостатков любимого предмета» (Михайловский 1878. 225) и рассуждения С. Н. Кривенко «о красавице-деревне и об отношении к ней литературных парней», о подозрениях, будто «Успенский ревнует к деревне других поклонников» (Кривенко 1879. 126) и т.п.), то в критическом дискурсе начала $\mathrm{XX}$ века был акцентирован религиозный смысл народнического «чувства».

В кенозисе интеллигента перед «евангельской святыней народа» (Д. С. Мережковский) русские критики разглядели черты христоподражательного подвига. Так, С. А. Венгеров в работе «Героический характер русской литературы» указывал на «серьезность, жгучесть, страстность русской народнической литературы семидесятых годов» (Венгеров 1911. 156): «И думалось разгоряченному уму, и верилось влюбленному сердцу, что стоит только окунуться в этот океан, чтобы совершенно с ним сродниться» (Венгеров 1911. 148). Критик считал, что «в Глебе Успенском это чисто-религиозное отношение к народному благу сказалось необыкновенною яркостью и прямою трагичностью» (Венгеров 1911. 156). Д. П. Мирский писал о «трагическом романе русского интеллигента с русским народом», отраженном «как в микрокосме» в творчестве Успенского (Мирский 2006. С. 306). Л. Д. Троцкий печальный итог народолюбия объяснял тем, что народническое чувство было направлено на «воображаемого» мужика. По словам Троцкого, русская интеллигенция пережила «роман с псевдомужиком» («Об интеллигенции» (1912) (Троцкий 
1991. 272). Непримиримым противником интеллигентского кенозиса выступил А. М. Горький. В статье «Разрушение личности» (1909) он писал: «Наиболее ярким примером разрушения личности стоит предо мною драма русской интеллигенции. Андреевич-Соловьев назвал эту драму романом, в котором Россия - "Святая Ефросинья", как именовал ее Глеб Успенский, возлюбленная, а интеллигент - влюбленный. Мне хочется посильно очертить содержание той главы романа, вернее, акта драмы, которая столь торопливо дописывается в наши дни нервно дрожащею рукою разочарованного влюбленного» (Горький 1949. 49). Напротив, критик Е. А. Соловьев (Андреевич), на которого ссылался Горький, скорбел об «оскудении народнического духа», считая, что «народничество не было только течением изящной литературы <..> оно было течением общественного мышления, давало литературе тон и, что важнее всякого тона, - идею» (Андреевич 1899. 349).

\section{Заключение}

Идея любви определяла отношение писателя-народника к крестьянству. В народнической прозе традиционный для беллетристики любовный конфликт развернулся - во всей своей эмоциональной напряженности - между представителями двух социальных сил: интеллигенцией и крестьянством. Залогом любви народники считали принесении своей личности в жертву безликой народной стихии. Писателям-народникам не удалось осуществить свой проект ни в литературе, ни в жизни. Но вопреки недостигнутым целям, они создали образ жертвенного народолюбия, энергия и красота которого действовали заразительно на поколения русских интеллигентов.

\section{Литература}

1- Андреевич Е. А. (1899). Очерки текущей русской литературы // Жизнь. 1899. № 12. C. $347-360$. 
2- Венгеров С. А. (1911). Героический характер русской литературы. СанктПетербург: Изд-во «Прометей».

3- Горький А. М. (1949). Собрание сочинений. В 30 m., Т. 24. Москва: Изд-во «Гослитиздат».

4- Дячук Т. В. (2020). Мортальное пространство русской деревни в прозе писателей-народников (П. В. Засодимский, Г. И. Успенский, Н. Е. КаронинПетропавловский) // Успехи гуманитарных наук. 2020. № 2. С. 265-271.

5- Дячук Т. В. (2020а). Инфантилизм народа как тема очерковой прозы писателей-народников // Научный диалог. 2020. № 2. С. 222-237. DOI: $10.24224 / 2227-1295-2020-2-222-237$.

6- Златовратский Н. Н. (1912). Собрание сочинений. В 8 m., Т. 6. СанктПетербург.

7- Златовратский Н. Н. (1951). Устои. История одной деревни. Москва: Изд-во «Гослитиздат».

8- Златовратский Н. Н. (1988). Деревенский король Лир: Повести, рассказы, очерки. - Москва: Изд-во «Современник».

9- Каронин-Петропавловский Н. Е. (1958). Сочинения. В 2 m., Т. 2. Москва: Издво «Гослитиздат».

10- Козьмин Б. П. (1933). Om 19 февраля $~ к 1$ марта. Москва: Изд-во политкаторжан.

11- Кривенко С.Н. (1879). Hовые всходы на народной ниве // Отечественные записки. 1879. № 2. С. 125- 152

12- Мачтет Г.А. (1958). Избранное. Москва: Изд-во «Государственное издательство художественной литературы».

13- Михайловский Н. К. (1878). Бытовые очерки // Отечественные записки. 1878. № 8. C. $223-227$.

14- Мокшин Г.Н. (2010). Эволюция идеологии легального народничества в последней трети XIX - начале XX вв. Воронеж: Изд-во «Научная книга».

15- Нефедов Ф. Д. (1937). Повести и рассказы. В 4 m. Т. 3. Москва.

16- Оболенский Л.Е. (1902). Литературные воспоминания // Исторический вестник. 1902. № 1. С. 129.

17- Плеханов Г.В. (1948). Глеб Успенский // Плеханов Г.В. Искусство и литература. Москва: Изд-во «Государственное издательство художественной литературы». С. $504-555$.

18- Салтыков-Щедрин М. Е. (1972). Собрание сочинений. В 20 m., Т. 13. Москва: Изд-во «Художественная литература». 
19- Святополк-Мирский Д. П. (2006). История русской литературы с древнейших времен по 1925 год. Т. 1. - Новосибирск: Изд-во «Свиньин и сыновья».

20- Троцкий Л. Д. (1991). Литература и револючия. Москва: Изд-во «Политиздат».

21- Успенский Г. И. (1940). Полное собрание сочинений. В 14 m., Т. 5. Москва. Ленинград: Изд-во «АН СССР».

22- Успенский Г. И. (1950). Полное собрание сочинений. В 14 m., Т. 7. Москва. Ленинград: Изд-во «АН СССР».

23- Успенский Г. И. (1949). Полное собрание сочинений. В 14 m., Т. 8. Москва. Ленинград: Изд-во «АН СССР».

24- Франк С.Л. (1990). Этика нигилизма // Вехи: сб. статей о русской интеллигенции. Москва. С. 175 - 210.

25- Эртель А. И. (1958). Записки Степняка. Очерки и рассказы. Москва: Изд-во «Гослитиздат».

\section{Bibliography}

1- Andreevich E. A. (1899). Ocherki tekushhej russkoj literatury // Zhizn'. 1899. № 12. S. 347-360.

2- Vengerov S. A. (1911). Geroicheskij harakter russkoj literatury. Sankt-Peterburg: Izd-vo «Prometej».

3- Gor'kij A. M. (1949). Sobranie sochinenij. V 30 t., T. 24. Moskva: Izd-vo «Goslitizdat».

4- Djachuk T. V. (2020). Mortal'noe prostranstvo russkoj derevni v proze pisatelejnarodnikov (P. V. Zasodimskij, G. I. Uspenskij, N. E. Karonin-Petropavlovskij)// Uspehi gumanitarnyh nauk. 2020. № 2. S. 265-271.

5- Djachuk T. V. (2020a). Infantilizm naroda kak tema ocherkovoj prozy pisatelejnarodnikov // Nauchnyj dialog. 2020. № 2. S. 222-237. DOI: 10.24224/22271295-2020-2-222-237.

6- Zlatovratskij N. N. (1912). Sobranie sochinenij. V 8 t., T. 6. Sankt-Peterburg.

7- Zlatovratskij N. N. (1951). Ustoi. Istorija odnoj derevni. Moskva: Izd-vo «Goslitizdat».

8- Zlatovratskij N. N. (1988). Derevenskij korol' Lir: Povesti, rasskazy, ocherki. Moskva: Izd-vo «Sovremennik».

9- Karonin-Petropavlovskij N. E. (1958). Sochinenija. $V 2$ t., T. 2. Moskva: Izd-vo «Goslitizdat».

10- Koz'min B. P. (1933). Ot 19 fevralja $k 1$ marta. Moskva: Izd-vo politkatorzhan. 
11- Krivenko S. N. (1879). Novye vshody na narodnoj nive // Otechestvennye zapiski. 1879. № 2. S. 125- 152

12- Machtet G. A. (1958). Izbrannoe. Moskva: Izd-vo «Gosudarstvennoe izdatel'stvo hudozhestvennoj literatury».

13- Mihajlovskij N. K. (1878). Bytovye ocherki // Otechestvennye zapiski. 1878. № 8. S. $223-227$.

14- Mokshin G. N. (2010). Jevoljucija ideologii legal'nogo narodnichestva v poslednej treti $H I H$ - nachale $H H v v$. Voronezh: Izd-vo «Nauchnaja kniga».

15- Nefedov F. D. (1937). Povesti i rasskazy. V 4 t. T. 3. Moskva.

16- Obolenskij L. E. (1902). Literaturnye vospominanija // Istoricheskij vestnik. 1902. № 1. S. 129.

17- Plehanov G. V. (1948). Gleb Uspenskij // Plehanov G. V. Iskusstvo i literatura. Moskva: Izd-vo «Gosudarstvennoe izdatel'stvo hudozhestvennoj literatury». S. 504 -555 .

18- Saltykov-Shhedrin M. E. (1972). Sobranie sochinenij. V 20 t., T. 13. Moskva: Izdvo «Hudozhestvennaja literatura».

19- Svjatopolk-Mirskij D. P. (2006). Istorija russkoj literatury s drevnejshih vremen po 1925 god. T. 1. - Novosibirsk: Izd-vo «Svin'in i synov'ja».

20- Trockij L. D. (1991). Literatura i revoljucija. Moskva: Izd-vo «Politizdat».

21- Uspenskij G. I. (1940). Polnoe sobranie sochinenij. V 14 t., T. 5. Moskva. Leningrad: Izd-vo «AN SSSR».

22- Uspenskij G. I. (1950). Polnoe sobranie sochinenij. V 14 t., T. 7. Moskva. Leningrad: Izd-vo «AN SSSR».

23- Uspenskij G. I. (1949). Polnoe sobranie sochinenij. V 14 t., T. 8. Moskva. Leningrad: Izd-vo «AN SSSR».

24- Frank S. L. (1990). Jetika nigilizma // Vehi: sb. statej o russkoj intelligencii. Moskva. S. $175-210$.

25- Jertel' A. I. (1958). Zapiski Stepnjaka. Ocherki i rasskazy. Moskva: Izd-vo «Goslitizdat».

\section{HOW TO CITE THIS ARTICLE}

Дячук, Т. (2021). "Love for the People": On the History of "Social Feelings\&quot; In Literary Populism of the 1870-1880s. Issledovatel'skiy Zhurnal Russkogo Yazyka I Literatury, 9(1). 109-125.

DOI: $10.52547 /$ iarll.17.109

URL: https://www.journaliarll.ir/index.php/iarll/article/view/142

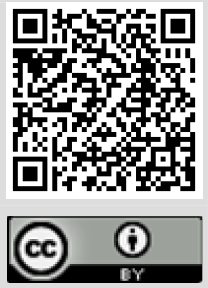




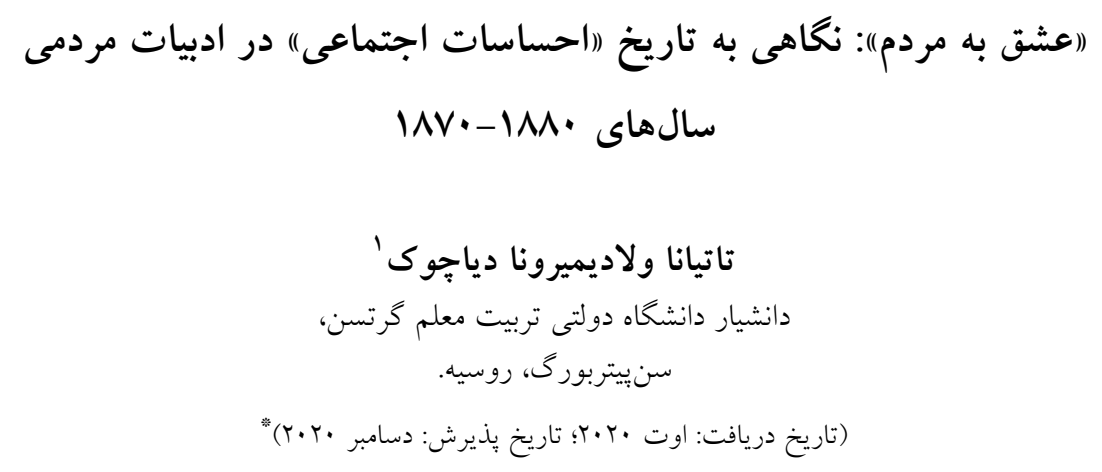

جكيده

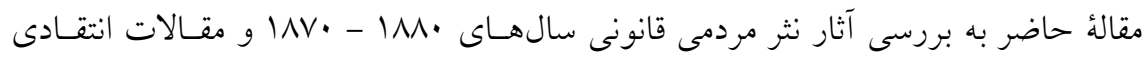

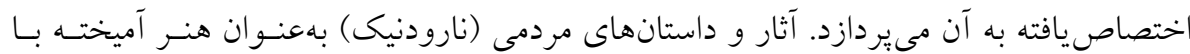

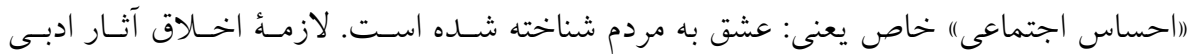
مردمى، انكار خود توسط روشنفكران و عشق به مردم رنجديله بـود. در همـان زمـان، تسصديق

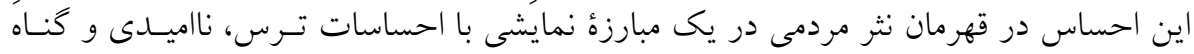

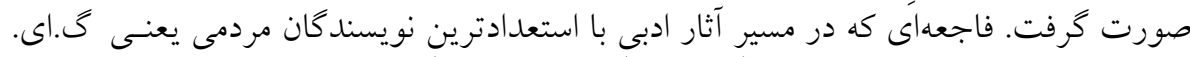

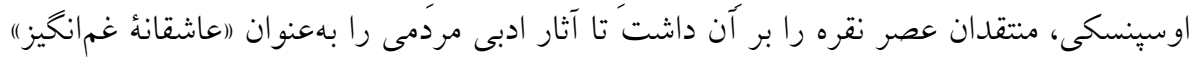

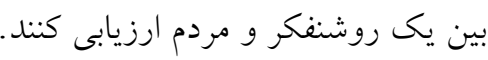

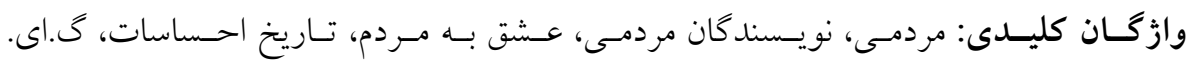

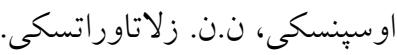

1. E-mail: Dia4uk.tanya@yandex.ru

$$
\text { * نوع مقاله: علمى - يزوهشى }
$$

